\title{
Şikâyet Kurumu, Takibi Şikâyete Bağlı Suçlar
}

\author{
Münevver İlay Vuslat Şahin \\ Erciyes Üniversitesi, Sosyal Bilimler Enstitüsü, Kamu Hukuku Yüksek Lisans Öğrencisi, Kayseri \\ av.ilayvuslat@gmail.com \\ ORCID ID: https://orcid.org/0000-0003-0631-7650
}

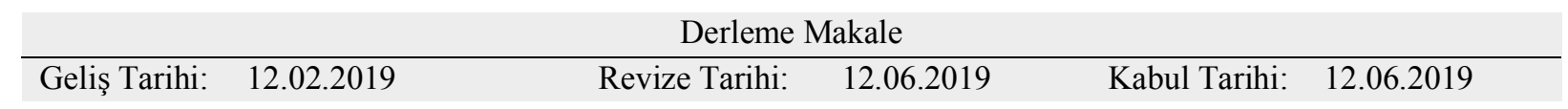

\section{Atıf Bilgisi}

Şahin, M. İ. V. (2019). Şikâyet kurumu, takibi şikâyete bağlı suçlar, Ahi Evran Üniversitesi Sosyal Bilimler Enstitüsü Dergisi, 5(1), 54-65.

\section{ÖZ}

Şikâyet, kovuşturma için şikâyet şartı aranan eylemlerde mağdurun, suçtan zarar görenin ya da yetkili temsilcilerinin; fiili ve faili öğrendiği tarihinden itibaren altı ay içerisinde, kanunda belirtilen yetkili makamlara yazılı veya tutanağa geçirilmek üzere sözlü olarak yaptığı, failin yahut fiilin cezalandırılması amacı taşıyan başvurusudur. Ekseriyetle şikâyet edilen fiilin kendisidir ve buna bağlı olarak failin adı verilmeden de şikâyet mümkündür. Bu çalışmanın amacı, 5237 Sayılı Türk Ceza Kanunu'nda şikâyet kurumunun yerinin, öneminin, niteliklerinin ve usulünün belirlenmesidir. Çalışmada öncelikle şikâyet kurumunun hukuki niteliğinin tartışılmış; kurumun ceza yargılaması açısından gerekli olup olmadığı, mevcudiyetinin amaca hizmet edip etmediği konularında fikir birliği bulunmadığı ve takibi şikâyete bağlı bir suçun icrası halinde hak sahibinin şikâyeti bulunmaksızın bu suça ilişkin soruşturma ve kovuşturma yapılamayacağı ortaya konulmuştur. Ceza hukuku bakımından şikâyet kurumu hem Türk Ceza Kanunu'nda (TCK) hem de Ceza Muhakemesi Kanunu'nda (CMK) yer almıştır. Şikâyet kurumu genel hatlarıyla TCK'nın 73. Maddesinde; "soruşturulması ve kovuşturulması şikâyete bağlı suçlar" başlığı altında usulü ise Ceza Muhakemeleri Kanunu'nda (CMK) düzenlenmiştir. Bu çalışmada şikâyet hakkına sahip olan kişi veya kişilerin kim olduklarına, şikâyet süresine ve usulüne dair bazı hususlar ile şikâyetten vazgeçme ve sonuçları gibi pek çok noktaya ilişkin tespitler ortaya konulmuştur.

Anahtar Kelimeler: Şikâyet, suç, takibi şikâyete bağlı suç, soruşturma ve kovuşturma.

\section{Complaint Institution, Tracking Complaint Crimes}

\begin{abstract}
The complaint is made orally, in order to be written or recorded in writing to the competent authorities specified in the law, for the purpose of investigating and prosecuting the crime within 6 months from the date of the actual and the perpetrator's learning, or the authorized representatives of the victim or offender who have been harmed by the victim or the crime due to the action attached to the complaint, is a statement of will for the purpose of punishing the offender. The aim of this study is to determine the place, importance and method of the complaint institution in the Turkish Penal Code numbered 5237. In the study, the legal nature of the complaint institution was discussed; It has been established that there is no consensus on whether the institution is necessary for criminal proceedings, whether the existence serves its purpose, and it is not possible to conduct an investigation and prosecution for this crime without the complaint of the right holder in the execution of an offense related to the complaint. In terms of criminal law, the complaint institution has been included both in the Turkish Penal Code (TCK) and in the Code of Criminal Procedure (CMK). In general terms of the complaint institution, Article 73 of TCK; the procedure iştir investigation and prosecution of offenses linked to the complaint $\mathrm{ul}$ is regulated in the Code of Criminal Procedure (CMK). In this study, some points about the person or persons who have the right to complain, some issues related to the duration of the complaint and the procedure and the findings related to the withdrawal and the consequences of the complaint have been identified.
\end{abstract}

Keywords: Complaint, crime, the crime that tracking is crime related to complaint, investigation and prosecution.

\section{Giriş}

Suç teşkil eden fiiller sosyal düzeni bozan ve bireylerin haklarını ihlal eden fiiller olması sebebiyle, hukuk düzeniyle koruma altına alınmış değerlere karşı bir zarar veya tehlikenin söz konusu olduğu durumlarda kural olarak yargılama makamı kendiliğinden harekete geçer. Çünkü devletin asli görevlerden biri de yargı organı aracılığıyla toplumsal ve bireysel menfaatleri korumak, düzeni bozucu 
nitelikteki fiilleri cezalandırıp, toplumsal adaleti temin etmektir. Ancak kimi durumlarda çeşitli gerekçelerle yargılama makamının doğrudan doğruya harekete geçme kuralına istisna getirilmiş ve soruşturma ve kovuşturma fonksiyonunun icrası bazı şartlara bağlanmıştır.

$\mathrm{Bu}$ şartlardan belki de en önemlisi şikâyet kurumudur. Anayasa'nın "Hak Arama Hürriyeti" başlıklı 36. maddesindeki, "Herkes, meşru vasita ve yollardan faydalanmak suretiyle yargı mercileri önünde davacı ve davalı olarak iddia ve savunma ile adil yargılanma hakkına sahiptir." ş̧eklindeki hüküm şikayet hakkının Anayasa ile güvenceye alındığının en büyük kanıtıdır. Dolayısıyla bir suçun işlendiğinden bahisle şikâyetçi olan kişi, kanunda kendisine tanınan hakkı kullanmış olduğu için hukuka uygun bir zeminde hareket etmektedir (Can, 2016). Bu çalışmada şikâyet konusuyla ilgili, şikâyet hakkının kime ait olduğu, hakkın kullanılacağı süre, hakkın kullanılma usulü, bu haktan feragat etme veya yapılmış olan şikâyetten vazgeçme gibi bazı tartışmalı hususlar ortaya konulmaya çalışılmıştır.

\section{Şikâyet Kurumu}

Şikâyet kurumu, anayasal bir hak olması sebebiyle hem Türk Ceza Kanunu'nda (TCK) hem de Ceza Muhakemesi Kanunu'nda (CMK) yer almıştır. Şikâyet kurumu genel hatlarıyla TCK'nın 73. Maddesinde; "soruşturulması ve kovuşturulması şikâyete bağlı suçlar" başlığı altında düzenlenmiştir. Buna göre; TCK Madde 73 - "(1)Soruşturulması ve kovuşturulması şikâyete bağlı olan suç hakkinda yetkili kimse altı ay içinde şikâyette bulunmadığ takdirde soruşturma ve kovuşturma yapılamaz.

(2) Zamanaşımı süresini geçmemek koşuluyla bu süre, şikâyet hakkı olan kişinin fiili ve failin kim olduğunu bildiği veya ögrendiği günden başlar.

(3) Şikâyet hakkı olan birkaç kişiden birisi altı aylık süreyi geçirirse bundan dolayı diğerlerinin hakları düssmez.

(4) Kovuşturma yapılabilmesi şikâyete bağlı suçlarda kanunda aksi yazılı olmadıkça suçtan zarar gören kişinin vazgeçmesi davayl düşürür ve hükmün kesinleşmesinden sonraki vazgeçme cezanın infazina engel olmaz.

(5) İştirak halinde suç işlemişs sanıklardan biri hakkındaki şikâyetten vazgeçme, diğerlerini de kapsar.

(6) Kanunda aksi yazll olmadıkça, vazgeçme onu kabul etmeyen sanı̆̆ etkilemez.

(7) Kamu davasının düşmesi, suçtan zarar gören kişinin şikâyetten vazgeçmiş olmasından ileri gelmiş ve vazgeçtiği sırada şahsi haklarından da vazgeçtiğini ayrıca açıklamış ise artık hukuk mahkemesinde de dava açamaz".

Türk Dil Kurumu sözlüğüne göre hak, "adaletin, hukukun gerektirdiği veya birbirine ayırdığ şey, kazanç" (TDK, 2018) anlamındadır. Şikâyet hakkı özel hukuktaki haklardan olmayıp, bir kamu hukuku yetkisidir. Özel hukuk anlamında hak, ferdin hukukça korunan menfaat veya varlıkların gerçekleştirilmesi veya korunmasına ilişkin irade beyanıdır. Esasen bu haklar kullanıldıktan sonra dönülmez, şarta bağlanamaz ve dürüstlük kurallarına uygun olarak kullanılır. Bu anlamda şikâyet özel hukuk anlamında "bir hak değil, bireye tanınmış bir kamu hukuku yetkisidir" (Erem, 2018). Bu bağlamda, şikayet hakkı, bir "sübjektif kamu hukuku hakkı"dır. Sübjektif kamu hukuku haklarının üç niteliği bulunmaktadır. Bunlar, fert ve kamu menfaatlerinin birlikte bulunması, ferdin hakkının karşısında devletin bir ödevi bulunması ve bu hakların bireyin hukuki ehliyetini genişletmesidir (Erem, Danışman ve Artuk, 2019).

Ceza Muhakemeleri Kanunu'nun (CMK) 158. maddesindeki ihbar ve şikâyetin usulüne ilişkin düzenlemelere yer verilmiş aynı kanunun 234. Maddesinde ise şikâyetçinin hakları sayılmıştır. Ayrıca İcra İflas Kanunu, Askeri Ceza Kanunu gibi özel hukuk alanına giren bazı kanunlarda da "şikâyet hakkı" konusuna yer verildiği görülmektedir. Bu çalışmada sadece çalışmanın konusunu oluşturan ceza hukuku açısından şikâyet kurumuna yer verilecektir.

Ceza Muhakemeleri Kanunu'nun (CMK) 158. maddesinde ihbar ve şikâyetin usulüne ilişkin düzenlemelere yer verilmiş aynı kanunun 234. Maddesinde ise şikâyetçinin hakları sayılmıştır. Ayrıca İcra İflas Kanunu, Askeri Ceza Kanunu gibi özel hukuk alanına giren bazı kanunlarda da "şikâyet 
hakkı" konusuna yer verildiği görülmektedir. Bu çalışmada sadece çalışmanın konusunu oluşturan ceza hukuku açısından şikâyet kurumuna yer verilecektir.

"Bir suç dolayısıyla soruşturma ve kovuşturma, kural olarak, mağdurun veya suçtan zarar görenin iradesine bakılmaksızın, kamu adına re'sen yapılır" (Özgenç, 2014). Ancak bazı suçlar dolayısıyla soruşturma ve kovuşturma yapılabilmesi için kanun, yetkili kişilerin şikâyette bulunması zorunluluğunu getirmiştir. Şikâyet, bir suçun tüm unsurlaryyla gerçekleşmesine rağmen, failin cezalandırılması için kanun koyucu tarafından getirilmiş zorunlu bir şarttır. Yani suç, şikâyetten bağımsız olarak tamamlanmıştır, ancak bu suç dolayısıyla soruşturma ve kovuşturma yapılması için şikâyet şartının gerçekleşmesi gerekmektedir (Erem, Danışman ve Artuk, 2019).

Şikâyet kavramı alanyazında farklı şekillerde tanımlanmıştır Özgenç'e göre (2014, s. 562) şikâyet; "mağdur veya suçtan zarar görenin yetkili mercie başvurarak, suç teşkil eden fiil dolayısıyla soruşturma ve kovuşturma yapılması yönündeki iradesini açıklaması”dır. Özbek, Kanbur, Doğan, Bacaksız ve Tepe'ye göre (2015, s. 133) "soruşturması ve kovuşturması şikâyete bağlı bir fiilden zarar gören kişinin, yetkili makamlardan bu fiil hakkında kovuşturma yapılmasını istemesine" şikâyet denir. Demirbaş ve Ertem'e göre (2018) "kanunda açıkça belirtile bazı suçlar nedeniyle suçtan zarar görenin kovuşturma arzusu"dur. Hakeri (2017) şikâyeti; "suçtan zarar gören kimsenin kovuşturulması şikâyete bağlı suçlarda ilgili makamlara suçun kovuşturulması iradesini bildirmesi” şeklinde tanımlamıştır. Centel, Zafer ve Çakmut (2014, s. 590) ise şikâyeti, "Suçtan zarar görenin ceza soruşturması yapılmasında sakınca görmediğini ve failin cezalandırılmasını istediğini belirtmesidir" diye tanımlamıştır.

Tüm bu tanımlarda geçen ortak noktalar dikkate alındığında; şikâyet, kanunda kovuşturma için şikâyet şartı aranan eylem nedeniyle mağdur veya suçtan zarar görenin ya da yetkili temsilcilerinin, fiili ve faili öğrendiği tarihinden itibaren 6 ay içerisinde, kanunda belirtilen yetkili makamlara yazılı veya tutanağa geçirilmek üzere sözlü olarak yaptığı, failin yahut fiilin cezalandırılması amacı taşıyan irade açıklamasıdır denilebilir (Şahin, 2014). Başka bir deyişle, belli suçlardan zarar görenlerin, ceza kovuşturmasının muhtemel sakıncalarına karşı korunmaları amacı ile bu suçlardan dolayı soruşturma ve kovuşturma, dolayısı ile 'muhakeme' yapılabilmesi için, kanunla konulmuş olan bir engelin kaldırılması şart koşulmuş ve bu engeli kaldırma işlemine şikâyet adı verilmiştir (Kunter, 2009).

\section{Şikâyet Hakkı}

Şikâyet hakk1, anayasal bir hak olup her suçta mümkündür. Şikâyet hakk1, bireyin devletten kendi menfaatine bir şey yapmasını isteyebilme hakkını ifade eden sübjektif kamu hukuku hakkıdır (Erem, Danışman ve Artuk, 2019). Şikâyet, "kamu davası açılmasından sonra da söz konusu olabilmektedir. Kovuşturma evresine geçildikten sonra suçun şikâyete bağlı olduğunun anlaşılması halinde, mağdur açıkça şikâyetten vazgeçmediği takdirde yargılamaya devam edilmektedir" (CMK 158/6).

Şikâyete bağlı suçların soruşturulması ve kovuşturulması ancak şikâyet hakkı sahibinin bu hakkı kullanmasıyla mümkündür. Şikâyet kendisine suç işlenen kişilerce yapılır. Şikâyet hakkı kişiye sıkı sıkıya bağlı haklardandır, bir istisnai durum dışında ${ }^{1}$ mirasçılara geçmez. Eğer şikâyeti buna yetkili olmayan bir kimse yapmış ise, şikâyet geçersizdir. "Suçtan zarar gören küçük ise kanuni temsilcisi şikâyet hakkını kullanır. Suçtan zarar görenin kanuni temsilcisi varsa şikâyeti o yapar” (Güngör, 2009). Türk Ceza Kanunu'nun 53. Maddesi gereğince 11 yaşından küçüklere hakkında cezaya hükmedilemez. Türk Ceza Kanunu'nun 54. maddesine göre 11 yaşını bitirmiş ve 16 yaşından gün almamış çocukların, işlemiş oldukları suçları fark ederek sorumluluklarını bilme yetisine sahip olup olmadıklarının tespit edilmesi gerekmektedir. Yaşının küçüklüğü nedeniyle, akli hastalığı ya da arizi sarhoşluk ve buna benzer nedenlerden biriyle makul surette hareket etmek iktidarından mahrum

\footnotetext{
${ }^{1}$ TCK'nın 131/2. Maddesine göre, hakaret ve sövme suçlarında şikâyet hakkının ölenin ikinci dereceye kadar üstsoy ve altsoyu ile eşi veya kardeşlerine geçmektedir.
} 
olmayan her şahıs Medeni Kanun'da mümeyyizdir. O halde "mümeyyiz" kelimesinin anlamı yasalarımıza bütünüyle dikkat edilecek olursa, bir şahsın aklının başında, yaptığı işin bilincinde olmasıdır (Dinçmen, 1984). Bu bağlamda "16, 17 ve 18 yaşındakiler işledikleri fiillerin anlam ve sonuçların algılama ve bu fiille ilgili olarak davranışlarını yönlendirme yetenekleri bulunduğundan şikâyet hakkını kullanırlar. 13, 14 ve 15 yaşındakiler ayırt etme gücüne (temyiz kudretine) sahip olduklarının anlaşılması halinde (doktor raporu ile) şikâyet haklarını kullanırlar" (Albayrak, 2008, s, 288).

\section{Şikâyetin Tasnifi}

Suçlar kural olarak re'sen soruşturulup kovuşturulur. Sadece kanun tarafindan bir suçun takibinin açıç̧a şikâyete bağlı olarak tasniflenmesi durumunda şikâyet söz konusu olmaktadır. (Güngör, 2009). Kanun şikâyeti bazı hallerde fiile bağlı olarak, bazı hallerde ise failin niteliğine göre düzenlemiştir. Bu anlamda şikâyete bağlı suçları, mutlak ve nispi olarak ikiye ayırmak mümkündür (Can, 2016). Bazı suçlar şikâyet şartı gerçekleşmeksizin mutlak olarak takip edilemeyen suçlardır. Örneğin, taksirle yaralama ( TCK m. 89 ), reşit olmayanla cinsel ilişki (TCK m. 104 ), cinsel taciz (TCK m. 105 ) suçları mutlak olarak takip edilen suçlardandır.

Re'sen kovuşturmaya tabi bazı suçların, birtakım nedenlerden dolayı, örneğin fail ile suçtan zarar gören arasındaki belirli derecedeki yakınlık dolayısı ile istisnaen şikâyet şartına tabi tutulma durumunu "nispi şikâyete bağlı suçlar" olarak açıklamak mümkündür (Demirbaş, 2018). Örneğin, hırsızlık suçu, belli derecede akrabalar tarafından işlenmesi halinde takibi şikâyete bağlanmıştır (TCK m. 167). Aynı şekilde nitelikli cinsel saldırı suçlarında şikâyet şartı aranmamasına, yani mutlak şikâyete bağlı suçlardan sayılmasına rağmen, bu suçun eşe karşı işlenmesi halinde, fiilin soruşturulması ve kovuşturulması şikâyete tabi tutulmuş olup nispi şikâyete bağlı suçlar arasında sayılmalidir (TCK. m.102/2).

\section{Şikâyetin Hukuki Niteliği}

Şikâyet kurumuna hem TCK'da hem CMK'da yer verilmesi ve kurumun ceza yargılaması üzerindeki fonksiyonu sebebiyle, şikâyetin maddi hukuka m1, yoksa usul hukukuna mı ait olduğu konusunda öğretide bazı tartışmalar mevcuttur. Şikâyetin hukuki niteliğini açıklamaya yönelik farklı görüşler ileri sürülmüştür. Aşağıda bu görüşlerden bazıları sunulmaktadır:

\section{Şikâyeti Usul Hukuku Kurumu Olarak Kabul Eden Görüş}

Literatürde ağırlıklı olarak kabul edilen görüş, şikâyetin Ceza Usul Hukuku alanına ait bir hak olduğu yönündedir (Centel, Zafer ve Çakmut, 2014; Koca ve Üzülmez, 2018; Öztürk, Tezcan, Erdem, Sırma, Kırıt Saygılar, Özüydın, Akcan Alan, Erden ve Tütüncü, 2015; Yenisey ve Nuhoğlu, 2014). Suç, şikâyetten bağımsız olarak tamamlanmıştır. Ancak bu suç dolayısıyla soruşturma ve kovuşturma yapılması için şikâyet şartının gerçekleşmesi gerekmektedir (Erem, Danışman ve Artuk, 2019).

Soruştuma makamları, şikâyet edildiği takdirde şikayate tabi suçlar bakımından suç teşkil eden fiilin cezalandırılması için kovuşturma aşamasına geçmektedir. Ancak şikâyet edilmediği takdirde ise kovuşturma aşamasına geçememektedir. Zira şikâyetten önce de, suç vardır. Şikâyet, suç hakkında kovuşturma başlatabilmek için gerçekleşmesi gereken bir şarttır. Yani devletin cezalandırmak hakkı şikâyetten gelmez ancak şikâyet muhakemeye engel olan durumu kaldırır.

Şikâyetin olmadığı durumlarda zamanaşımı süresi, şikâyet tarihinden değil suç tarihinden itibaren işlemeye başlamakta, cezalandırılabilme şartı söz konusu olan suçlarda bu şart gerçekleşmediğinde teşebbüs söz konusu değilken şikâyete bağlı suçlarda teşebbüs cezalandırılabilmektedir. Cezalandırılabilme şartı olan şikâyet gerçekleşmediğinde ise o suç açısından düşme kararı verilmektedir. Zira şikâyet, suç hakkında, muhakeme faaliyetine girişebilmek için gerçekleşmesi lazım gelen bir şart niteliğindedir. Buna rağmen şikâyet şartı gerçekleşmediğinde bütün unsurları ile oluşmuş bir suça ceza yasasının uygulanmasına engel olan şikâyet şartı, ceza muhakemesi 
kurumu, yani, muhakeme şartı olarak kabul edilse dahi, lehe-aleyhe değerlendirilmesi yapılarak "derhal uygulanırlık" ilkesi yerine lehe olan düzenleme şeklinin uygulanması gerekir (Demirtaş, 2018).

\section{Şikâyeti Maddi Ceza Hukuku Kurumu Olarak Kabul Eden Görüş}

Şikâyet kurumunu düzenleyen genel hükümler, Türk Ceza Kanunu'nda düzenlenmiştir. Şikâyetin düzenlendiği yeri göz önünde bulunduran kimi yazarlar, hukukçular onun maddi ceza hukuku kurumu olduğu fikrini ileri savunmaktadırlar. Buna göre şikâyet, kovuşturmayı sağladığı için muhakeme hukuku ile yakından ilgilidir fakat cezalandırmayı sağlaması bakımından maddi ceza hukukunun kapsamına da girer. Nitekim bu koşullar somut olarak failin cezalandırılmasını önledikleri için maddi ceza hukuku içerisinde yer alan suç teorisi içerisinde incelenmesi gerekir. Ayrıca bu koşulların ceza kanununda düzenlenmiş olması da konunun maddi ceza hukuku ile bağlantısını vurgulamaktadır (Can, 2016; İçel, 2014 ). Şikâyetin, bir ceza hukuku kurumu sayılması halinde, zaman bakımından uygulamada lehteki kanunun uygulanması ilkesi şikâyet kurumu hakkında da geçerli olacaktır.

Literatürde ağırlıklı olarak kabul gören ve bizim de katıldığımız görüş, şikâyetin usul hukuk kurumu olduğu yönündedir. Zira suç şikâyetten bağımsızdır ve kovuşturmanın başlatılabilmesi için usûli bir veri olan şikâyet şartının gerçekleşmesi gerekir.

\section{Suçların Takibinin Şikâyete Bağlanmasının Nedenleri}

Bazı suçlar için kanun koyucu tarafından soruşturma ve kovuşturma yapılabilmesi için, yetkili kişilerin şikâyette bulunması zorunluluğu getirilmiştir. Ancak ülkeler suç unsuru oluşturan fiillerin nasıl soruşturulup kovuşturulacağına ilişkin farklı sistemler benimsemişlerdir. Aynı ülkede bile tarihsel süreç içerisinde farklı sistemler, uygulamalar söz konusu olmuştur. Türk Hukuk Sisteminde de 1412 Sayılı mülga Ceza Muhakemeleri Usulü Kanunu ile 5271 Sayılı CMK'nın konuya bakış açıları birbirinden farklıdır.

Ceza muhakemesi hukukunda kovuşturma mecburiyeti ilkesinin karşıtı "maslahata uygunluk" ilkesidir. Maslahat, kamu yararı anlamına gelmektedir. Dava açmada mecburiyeti değil, kamu yararını kabul eden bu sistemde her dava için maslahata uygunluk olarak tabir edilen "lüzum" şartı aranmaktadır (Can, 2016; Uğur, 2007). Mecburilik ilkesinin aksine maslahata uygunluk ilkesi kabul edildiği takdirde, yetkili makamlar gerekli soruşturmayı yaptıktan sonra ayrıca dava açmada kamu yararı bulunup bulunmadığını araştırmak zorunda kalacaklardır (Demirtaş, 2018). Böyle durumlarda ceza davası açmak ve yürütmek devletin hem hakkı hem de görevidir.

1412 Sayılı Ceza Muhakemeleri Usulü Kanunu'nda sinırlı da olsa maslahata uygunluk ilkesi yer almaktayken 344. maddesi ile ortaya konulan çeşitli suçlarda suçtan zarar görene şahsi dava açma hakkı verilmiştir. Bu suçlarda ayrıca kamu davası da açılabilmektedir. Ancak eğer kamu davası açılmış ise aynı suça şahsi dava açılamamaktadır.

5271 Sayılı CMK ise şahsi davayı kaldırmış ve bütün suçların takibini Cumhuriyet Savcısının yetkisine bırakmıştır. Çünkü bu sistemde "kamu davasının mecburiliği" ilkesi benimsenmiştir. Ne varki, CMK'nın en temel prensiplerinden birisi olmasına rağmen 5217 Sayılı CMK'nın kabul ettiği kamu davasının mecburiliği ilkesi mutlak şekilde uygulanmamaktadır. Zira CMK'nın 171. Maddesi ile bu kurala istisna getirilmiş, Cumhuriyet Savcısına kamu davası açma konusunda takdir yetkisi tanınmıştır. Buna göre; "cezayı kaldıran şahsî sebep olarak etkin pişmanlık hükümlerinin uygulanmasını gerektiren koşulların ya da şahsî cezasızlık sebebinin varlığı halinde, Cumhuriyet savcısı kovuşturmaya yer olmadığı kararı verebilir" ve "Cumhuriyet Savcısının kamu davasının açılmaması hususunda takdir yetkisini kullandığı hâllerde bu kararına itiraz edilemez" (CMK, m. 173/5) hükmü getirilmiştir. CMK m. 171 ile getirilen diğer bir istisna da "Cumhuriyet Savcısı, soruşturulması ve kovuşturulması şikâyete bağlı olup, üst sınırı bir yıl veya daha az süreli hapis cezasını gerektiren suçlardan dolayı, yeterli şüphenin varlığına rağmen, kamu davasının 
açılmasının beş yıl süreyle ertelenmesine karar verebilir" hükmüdür. Bu maddelere istinaden, Cumhuriyet Savcısı ilgili maddede bulunan diğer şartların da varlığı halinde soruşturulması ve kovuşturulması şikâyete bağlı suçlar açısından yeterli şüphe bulunsa bile takdir hakkını kullanabilecektir (Can, 2016).

CMK geniş ölçüde "kamu davasının mecburiliği" ilkesini kabul etmiştir. Ancak zaman içerisinde işlenen suçların artması ile kamu davasının mecburiliği prensibine dayanan klasik muhakeme usulü uygulanamaz hale gelmiş ve zamanla tarafların iradeleri de söz konusu edilmiştir. Bu prensibi esnek hale getirmek için kullanılan ilk araç, "şikâyet" kurumu olmuştur. (Yenisey, 2013). Şikâyetin gayesi başlangıçta, suçtan zarar görenin sanığın cezalandırılmasını isteyip istemediğinin belirlenmesi iken, daha sonraları bu amacın yerini "suçtan zarar göreni korumak" prensibi almıştır (Kısık, 1992; Yenisey ve Nuhoğlu, 2013). Bir suçun faili ile mağduru arasındaki yakınlık da şikâyet kurumunun kabul edilmesinin gerekçeleri arasında sayılmıştır. Bu yolla kanun koyucu bazı suçların (hakaret, tehdit, mala zarar verme, bilgi vermeme vb.) soruşturulması ve kovuşturulmasını şikâyete bağlayarak, uyuşmazlığın aile içerisinde çözülmesine imkân sağlamıştır (Yılmaz, 2010).

\section{Şikâyet Süresi}

Şikâyet süresi TCK Madde 73'te şu şekilde belirlenmiştir: "(1)Soruşturulması ve kovuş̧urulması şikâyete bağlı olan suç hakkında yetkili kimse altı ay içinde şikâyette bulunmadiğı takdirde soruşturma ve kovuşturma yapılamaz; (2) Zamanaşımı süresini geçmemek koşuluyla bu süre, şikâyet hakk olan kişinin fiili ve failin kim olduğunu bildiği veya ögrrendiği günden başlar ve (3) Şikâyet hakkı olan birkaç kişiden birisi altı aylık süreyi geçirirse bundan dolayı diğerlerinin hakları düşmez”.

Şikâyete tabi suçlarda şikâyet süresi, mağdurun fiil ve faili öğrenmesinden itibaren 6 aydır. Yani TCK Madde 73/1 ve 2'ye göre müştekinin şikâyet hakkını kullanabilmesi için hem faili hem de fiili öğrenmesi gerekmektedir. Suçtan zarar gören veya mağdur, suçu oluşturan fiil veya failden herhangi birini geç öğrenmesi durumunda, 6 aylık şikâyet süresi fiil ve faili öğrendiği tarihten itibaren başlar. Ancak her ne kadar şikâyet süresi kanun maddesinin birinci fikrasında 6 ay olarak belirtilmişse de aynı maddenin ikinci fikrasında "zamanaşımı süresini geçmemek koşuluyla" ibaresi göz önünde bulundurulduğunda, bu hakkın kullanılabileceği altı aylık sürenin de dava zamanaşımı içerisinde bulunması gerekmektedir. Bu süre kesin olup, sürenin geçmesinden sonra şikâyet hakkı kullanılamaz. Şikâyet süresi, hukuki mahiyeti itibariyle hak düşürücü süre olarak kabul edilir. Hak düşürücü süre, bir hakkın kullanılması için yapılması gereken işlemin süresi içinde yapılmaması sonucunda hakkın düşmesine neden olan süredir (Güngör, 2009).

Zamanaşımını düzenleyen TCK'nın 66. maddesinin 1. fikrasının (e) bendine göre; "beş yıldan fazla olmamak üzere hapis veya adli para cezasını gerektiren suçlarda zamanaşımı sekiz yıl olarak öngörülmüştür. Şikâyete tabi suçların cezasının üst sınırı genellikle iki yılın altında olduğundan bu suçların büyük bir çoğunluğunda da zamanaşımı sekiz yıldır. Ancak bazı haller de farklı zamanaşımına tabi suçlarda vardır (TCK'nın 102. maddenin 2. fikrasındaki istisnada ${ }^{2}$ olduğu gibi" (Albayrak, 2008).

Müştekinin birden fazla olduğu durumlarda, müştekilerden birinin şikâyet süresi içerisinde bu hakkını kullanmaması durumunda, şikâyet süresi içerisinde olmak kaydıyla diğer müştekilerin şikâyet hakları devam etmektedir. Bu durum TCK'da "Şikâyet hakkı olan birkaç kişiden birisi altı aylık süreyi geçirirse bundan dolayı diğerlerinin hakları düşmez." (TCK md. 73/3) şeklinde ifade edilmiştir.

\footnotetext{
2 TCK m. 102: "Yaş grupları için değişik zamanaşımı süreleri kabul etmesi nazara alındığında büyükler için zamanaşımı 8 yıl, ilaveli zamanaşımı 4 yıl ve toplam zamanaşımı ise 12 yıl; fiili işlediği sırada 16,17 ve 18 yaşındaki kişiler için aslı zamanaşımı 5 yıl 4 ay, zamanaşımının uzaması 2 yıl 8 ay ve toplam zamanaşımı 8 yıl; 13,14 ve 15 yaşındakiler için ise asli zamanaşımı 4 yıl, zamanaşımının uzaması 2 yıl ve toplam zamanaşımı ise 6 yıl"dır.
} 
Yani müştekilerden her birinin şikâyet hakkı diğerinden bağımsızdır, tüm müştekilerin süresi dolana kadar her zaman şikâyetçi olunabilir (Toroslu ve Feyzioğlu, 2013). "Şikâyet süresi içinde kamu davasına katılma talebi aynı zamanda süresinde şikâyet olarak da kabul edilir" (Albayrak, 2008, s. 289).

\section{Şikâyetten Vazgeçme ve Hakkından Feragat Etme}

Soruşturulması ve kovuşturulması şikâyete bağlı bir suçun icrası sonucunda şikâyet hakk1 sahibinin süresi içerisinde ve kanunun öngördüğü şartlara uygun olarak bu hakkını kullandıktan sonra, şikâyetini geri almasına şikâyetten vazgeçme denir. Yani şikâyetten vazgeçme, "önceden yapılmış olan şikâyetin geri alınması ve geçersiz sayılmasının istenmesi"dir. TCK'nın 73/4, 5 ve 6 . fikralarında şikâyetten vazgeçme açıkça yer almaktadır. Takibi şikâyete bağlı suçların tamamında, şikâyet hakkı sahibinin şikâyetinden vazgeçmesi mümkün kılınmıştır.

Şikâyet hakkı anayasl bir haktır. Bu hak, istenilirse kullanılmayabilir. Bu kullanmayış, yani vazgeçme, Kanunda (TCK 73/4, 5, 6, 7) adı geçen "vazgeçme" değildir. Literatürde genel olarak "vazgeçmek hakkı" bu hakkı hiç kullanmamak olarak açıklamaktadır. Kullanılan şikâyet hakkının "geri alınması" anlamındaki "vazgeçme”yi kanun düzenlemiştir. Kanun, şikâyetin geri alınabileceğini kabul etmiştir: "Mahkûmiyet kararı kesinleşinceye kadar şikâyet geri alınırsa (vazgeçilirse), dava düşer" (TCK 73/4). Şikâyetten vazgeçme, soruşturma aşamasında takipsizlik kararı, kovuşturma aşamasında kamu davasının düşmesi sonucunu doğurur. Kovuşturma evresine geçtikten sonra suçun şikâyete tabi olduğu anlaşılırsa, "mağdur açıkça şikâyetinden vazgeçmemiş ise yargılamaya devam olunur" (CMK 158/6). Hüküm kesinleştikten sonra şikâyetten vazgeçildiği beyan edilse bile bu durum cezanın infazına engel olmaz. Ayrıca şikâyetten vazgeçmeden sonra bu vazgeçmeyi geri alma, yani vazgeçmeden vazgeçmek mümkün değildir (Albayrak, 2008).

Feragat, TDK' da (2018) "Hakkından kendi isteğiyle vazgeçme." olarak tanımlanmaktadır. Hukuk dilinde feragat, şikâyete bağlı bir suçun icrası neticesinde suçtan zarar görenin, şikâyet süresi dolmadan şikâyet hakkını kullanmayacağını yetkili makamlara bildirmesidir (Centel, Zafer ve Çakmut, 2014; Demirtaş, 2018). Hakkından feragat etmek, "vazgeçmek"ten farklı olarak, henüz hiç şikâyetçi olmadan hakkı kullanmamaktır. Oysa vazgeçmek bu hakkın kullanılması işleminin başlatılmasından sonra hakkın kullanılmasından geri adım atılması sürecini içerir. Şikâyetten vazgeçme ile ilgili durum 5237 Sayılı TCK'nın 73. maddesinde açıkça ortaya konulmuşken; feragat, TCK'da açıkça düzenlenmemiştir. Ancak, uygulamada kabul edildiği Yargıtay kararlarından anlaşılmaktadır ${ }^{3}$.

Şikâyetten feragat ancak şikâyet hakkı doğduktan sonra mümkündür. Aynı şekilde şikâyetten feragat, ancak şikâyet süresi dolmadan mümkündür, süre geçtikten sonra yapılan feragat, ortada kullanılabilecek bir hak bulunmadığından yani suç zaman aşımına uğradığından bir anlam ifade etmeyecektir (Yaşar, Gökcan ve Artuç, 2014). Zaman bakımından uygulanmada şikâyetten vazgeçme ile ilgili literatürde uzmanların farklı görüşler ileri sürdükleri görülmektedir. Şikâyetin Maddi Ceza Hukuku kurumuna ait olduğunu ileri süren uzmanlara göre; "ceza hukukunun en önemli ilkesi olan, ceza hukuku kurallarının yürürlüğe girdikleri andan itibaren işlenen suçlara uygulanması gerektiği" kuralından hareketle ileriye etkili olma prensibi ve bu ilkenin istisnasını oluşturan failin lehine olan yasanın geçmişe etkili olması kuralınca "geçmişe etkili uygulama" veya "geçmişe yürürlük" söz konusudur. Bu ilkelere istinaden failin lehine hükümler içeren yasa, suçtan sonra yürürlüğe girmiş olsa da hüküm ve infaz aşamasında dikkate alınmalıdır.

Şikâyetin Ceza Muhakemesi Hukuku'na ait olduğunu savunan uzmanlar ise (Artuk, Gökcen, Yenidünya, 2007; Erem, Danışman ve Artuk, 2019; Şahin, 2007) “derhal uygulanması ilkesi”ni benimsemektedirler. $\mathrm{Bu}$ ilke, usule ilişkin yeni yasanın eskisinden daha yeterli ve daha yararlı olduğunu kabul etmekte ve ülkede aynı anda benzer durumlar için birden çok yargılama yasasının geçerli gerektiğini savunmaktadırlar. Bu durumda; "derhal uygulanırlık ilkesinin doğal sonucu olarak, usul işlemleri, yapıldığg sırada yürürlükte bulunan yargılama yasası hükümlerine tâbi olacak ve ceza

\footnotetext{
${ }^{3}$ Örneğin, Yargitay Ceza Genel Kurulunun 02.03.2004 tarih ve 2004/2-44 Esas ve 2004/58 Karar sayılı kararı.
} 
yargılaması sırasında, yasada değişiklik olduğunda yeni yasa hemen uygulanacak, ancak, bu durum, önceki yasanın yürürlükte bulunduğu dönemde, o yasaya uygun biçimde yapılmış işlemlerin geçersizliği sonucunu doğurmayacağı gibi yenilenmesini de gerektirmeyecektir" (Yargıtay Ceza Genel Kurulu 2006/9-44 E., 2006/54 K.).

Ceza Muhakemesi Kanununda gerek öğretide gerekse Yargıtay içtihatlarından da bahsedildiği üzere 'Derhal Uygulanırlık Illkesi' söz konusu olduğundan şikâyet kurumunun da CMK' ya ait bir kurum olduğu göz önüne alındığında yasa değiştiği zaman, leh ya da aleyhe olduğuna bakılmaksızın derhal uygulanması gerekir. Şahin, (2007) "ş̧ikâyetin TCK'da düzenlenmiş olması, onun bir CMK ve muhakeme şartı olma niteliğini değiştirmediği”" görüşünü belirtmektedir.

\section{Takibi Şikâyete Bağlı Suçlar}

TCK'da suçlar kural olarak re'sen araştırma ilkesine tabidir. Ancak bu kuralın istisnalarından bir tanesi de şikâyet kurumudur. Suçun kanuni tanımında "mağdurun şikâyeti üzerine" veya "şikâyet üzerine" ifadeleri varsa, o suç şikâyete bağlı bir suçtur; suçtan zarar görenin, mağdurun veya yasal temsilcisinin kanunda belirtilen yetkili makamlara yazılı veya tutanağa geçirilmek üzere sözlü olarak yaptığı irade açıklaması neticesinde yapılan soruşturma veya kovuşturma re'sen araştırma ilkesinin istisnasıdır. Kanunda böyle bir ifade yer almaması durumunda ise söz konusu suç şikâyete bağlı bir suç olmaktan çıkar. Nitekim aşağıdaki suçlar bu şekilde şikâyete bağlı kılınmıştır.

Türk Ceza Kanunu'nda şikâyete tabi suçların bulunduğu maddelerden bazıları aşağıda verilmiştir (Albayrak, 2008):

"TCK. 11/2 Yurt Dışında Vatandaş Tarafından İşlenen Suç

TCK. 12/2 Yurt Dışında Yabancı Tarafından İşlenen Suç

TCK. 86/2 Kasten Basit Yaralama

TCK. 89 Taksirle Yaralama (Bilinçli taksir hariç)

TCK. 102/1 Basit Cinsel Saldırı

TCK.102/2- (2.Cümle) Nitelikli Cinsel Saldırının eşe karşı işlenmesi

TCK 104/1 Reşit Olmayanla Cinsel İlişki

TCK. 105/1 Basit Cinsel Taciz

TCK.106/1- (2. Cümle) Malvarlığını zarara uğratacağı ve sair kötülükle tehdit

TCK. 116/1 ve 2 Konut ve İşyeri Dokunulmazlığının İhlali

TCK. 117/1 İş ve Çalışma Hürriyetinin İhlali

TCK. 123 Kişilerin huzur ve sükûnunu bozma

TCK. 125 Hakaret (TCK. 125/3-a hariç)

TCK. 132 Haberleşmenin Gizliliğini İhlal

TCK. 133 Kişiler arasındaki konuşmaların dinlenmesi ve kayda alınması

TCK. 134 Özel hayatın gizliliğini ihlal

TCK. 144 Paydaşın veya elbirliği ile malikin hırsızlığı veya hukuki ilişkiye dayanan alacağı tahsil amaciyla hırsızlık

TCK. 146/1 Kullanma Hırsızlı̆̆

TCK. 151 Mala Zarar Verme

TCK. 155/1 Güveni Kötüye Kullanmanın basit şekli (2. fikra hariç)

TCK. 156 Bedelsiz Senedi Kullanma

TCK. 159 Hukuki alacağı tahsil amacıyla dolandırıcılık

TCK. 160 Kaybolmuş veya hataen ele geçmiş eşyanın tasarrufu

TCK. 167/2 Yağma hariç yakın akrabanın işlediği malvarlığı suçları

TCK. 209/1 Açığa İmzanın Kötüye Kullanılması

TCK. 233/ 1 Aile hukukundan kaynaklanan yükümlülüğün ihlali

TCK. 239/1, 2 ve 3 Ticari Sır, Bankacılık Sırrı veya Müşteri Sırrı Niteliğindeki Bilgi veya Belgelerin Açıklanması

TCK. 340/ 2 Yabancı devlet başkanına karşı suç

TCK. 341/ 2 Yabancı devlet bayrağına karşı hakaret

TCK. 342/ 2 Yabanc1 Devlet Temsilcilerine Hakaret”. 


\section{Şikâyet Hakkının Kullanılma Usulü}

"Şikâyet yazılı veya tutanağa geçirilmek üzere sözlü olarak yapılabilir" (CMK m. 158/5). Şikâyet, suçtan zarar görenin bu suçtan dolayı dava açılmasını talep etmesidir. Bu talebin şikâyete yetkili kimse tarafından, "şikâyetçiyim, yakınıyım, davacıyım, ihbar ediyorum, cezalandırılmasını isterim gibi herhangi bir tabir kullanması yeterlidir" (Koca ve Üzülmez, 2018; Kunter, Yenisey ve Nuhoğlu, 2013; Şahin, 2014). "Soruşturma veya kovuşturulması şikâyete bağlı suçlarda, önceden usulüne uygun şikâyet olmasa da, şikâyet süresinin geçirilmemesi koşuluyla, yargılama sırasında mağdurun şikâyetçi olduğunu söylemesi ve bunun duruşma tutanağına geçirilmesiyle yapılan şikâyet de geçerli olur. Böylece, hak düşümü süresinde olması şartıyla, mahkemeye verilecek davaya katılma dilekçesi veya duruşma tutanağına geçirilecek beyanla şikâyet yokluğu ortadan kaldırılmış olur" (Şahin, 2014).

"Şikâyet" ile "yazılı başvuru" arasında büyük bir benzerlik varsa da, korudukları hukuki menfaatten kaynaklanan bazı farklar vardır. Yeni TCK müracaat koşulunu kaldırmış ve müracaata bağlı suçları şikâyete bağlı hale getirmiştir. Bu nedenle yazılı başvuru şartı yerine "şikâyet" kurumu işlevsel hale gelmiştir. Yani, "yazılı başvuru, şikâyet değil ise de, artık şikâyet gibi ele alınması gereken bir kurumdur” (Yenisey ve Nuhoğlu, 2013).

TCK, şikâyeti bazı hallerde fiile bazı hallerde faile bağlı olarak düzenlendiği için, şikâyete bağlı suçları, mutlak ve nispi olarak ikiye ayırmak mümkündür. "Şikâyet şartı gerçekleşmeden takip edilemesi mümkün olmayan suçlar" mutlak şikâyete bağlı suçlardır. Ö̈neğin, taksirle yaralama ( TCK m. 89 ), reşit olmayanla cinsel ilişki (TCK m. 104 ), cinsel taciz (TCK m. 105 ) mutlak şikâyete bağlı suçlardandır. Nispi şikâyete bağlı suçlar ise "esasta resen soruşturulan ve kovuşturulan suçlar olmakla birlikte, bazı şartların bulunması halinde şikâyete tabi olan suçlar"dır (Dönmezer ve Erman, 2016). Örneğin, hırsızlık suçunun belli derecede akrabalar tarafından işlenmesi halinde takibi şikâyete bağlanmıştır ( TCK m. 167 ). Aynı şekilde nitelikli cinsel saldırı suçu esasen resen takip edilmekle birlikte, eşe karşı bu suçun işlenmesi halinde, fiilin soruşturulması ve kovuşturulması şikâyete tabi tutulmuştur (TCK m.102/2).

\section{Sonuç}

Çalışmada, Türk Ceza Kanunumuzun 73. maddesi tüm yönleri ile alınmaya çalışılmıştır. Şikâyet kurumunun, Türk Ceza Hukuku Özel Hükümler ve Ceza Muhakemeleri Hukuku kapsamında ayrıntılı bir şekilde değerledirilmesi yapılarak; hangi suçların şikâyete tabi olduğu, hangi suçların şikâyete tabi olmadığı ana hatlarıyla aktarılmaya çalıştışılmış daha sonra; konuya ilişkin teorik açıklamalar Yargıtay kararları ile zenginleştirilmiş ve konu hakkında kendi görüşlerimize de yer verilmiştir.

Ceza hukukunun amac1, suç teşkil eden fiil işlendiği zaman, kanunda öngörülen müeyyide ile fail cezalandırılarak toplumdaki huzuru ve güveni sağlamaya çalışmak olduğu kadar, toplumdaki insanların suç işlemekten sakınmalarını sağlamak ve hukuken menfaatlerini korumaktır.

Suç teşkil eden bir fiil ortaya çıktığı zaman, kural olarak mağdurun veya suçtan zarar görenin iradesine bakılmaksızın, soruşturma ve kovuşturma kamu adına resen yapılmaktadır. Çünkü her müeyyidenin temelini kamu yararı oluşturmaktadır. Ancak bu durum bazı hallerde tarafların zor durumda kalmasına sebebiyet vermektedir. Bu yüzden de kanun; tarafların iradelerini ve suçtan zarar göreni korumak, daha etkin yargılama yapılmasını sağlamak ve muhakeme sürecini kısaltmak gibi etkenleri bir arada düşünerek esneklik getirmiştir. Bu esnekliklerden biri de muhakemeye engel bir kurum olan şikâyet kurumudur.

Şikâyet kurumu soruşturma açılmasını engelleyen ya da soruşturma sonunda dava açılmasını engelleyen bir kurumdur. Kanunumuzda ayrıntılı bir şekilde düzenlenmiştir. Şikâyet kurumunun asıl amacı mağduru korumak, yani failin mağdura vereceği zarardan yine mağduru korumaya çalışmaktır. 
Şikâyet kurumu üzerinde en çok tartışılan husus da kurumun hukuki niteliğidir. Şikâyetin düzenlendiği yeri göz önünde bulunduran kimi uzmanlar (Can, 2016; İçel, 2018) şikâyetin maddi ceza hukukuna ait olduğunu savunmaktadır. Ancak doktrinde en çok kabul edilen (Artuk, Gökcen, Yenidünya, 2007; Erem, Danışman ve Artuk, 2019; Şahin, 2007) ve tarafımızca da benimsenmiş olan görüş; muhakeme yapılması şikâyet şartına bağlandığı için, Ceza Muhakemesi Kurumu olduğu ve bu nedenle de derhal uygulanırlık prensibine tabi olduğu yönündedir.

\section{Kaynaklar}

Albayrak, M. (2008). Şikâyete tabi suçların özellikleri ve bu suçlara bağlanan hukuki sonuçlar, Tbb Dergisi, 77, Ss. 281-306.

Can, S. (2016). Ceza hukukunda şikâyet. Yayımlanmamış Yüksek Lisans Tezi, Kırıkkale Üniversitesi, Kirikkale.

Centel N., Zafer, H. ve Çakmut Ö. (2014). Türk ceza hukukuna giriş, (8. Bask1). İstanbul: Beta Yayınlar1.

Demirbaş, T. (2018). Ceza hukuku genel hükümler, (13. Bask1). Ankara: Seçkin Yayınları.

Demirbaş, T. ve Erdem, M. R. (2018). Ceza hukuku pratik çalışmalar, (9.Baskı). Ankara: Seçkin Yayınevi.

Demirtaş, E. (2008). Ceza muhakemesi hukukunda muhakeme şartı olarak şikâyet. Yayımlanmamış Yüksek Lisans Tezi, Selçuk Üniversitesi, Konya.

Dinçmen K. (1984). Adli psikiyatri. İstanbul: Birlik Yayınları.

Dönmezer, S. ve Erman, S. (2016). Nazari ve tatbiki ceza hukuku Cilt I, (14. Bask1). İstanbul: Beta Yayınlar1.

Erem, F., Danışman, A. ve Artuk, E. (2019). Ceza hukuku genel hükümler, (13. Bask1). Ankara: Seçkin Yayınevi.

Erem, F. (2018). Borçlar hukuku genel hükümler, (23. Baskı). Ankara: Yetkin Yayınları.

Güngör, D. (2009). 5237 ve 5271 sayılı kanunlar ışı̆̆ında şikâyet kurumu. Ankara: Yetkin Yayınları.

Hakeri, H. (2017). Ceza hukuku genel hükümler, (21. Bask1). Ankara: Adalet Yayınevi.

İçel, K. (2018). Ceza hukuku genel hükümler, (5. Baskı). Ankara: Beta Yayınları.

Kısık, S. (1992). Bir kovuşturma şartı olarak şikâyet. Yayımlanmamış Yüksek Lisans Tezi, İstanbul Üniversitesi, İstanbul.

Koca, M. ve Üzülmez, İ. (2018). Türk ceza hukuku genel hükümler, (11. Bask1). Ankara: Seçkin Yayınevi.

Kunter, N. (2009). Muhakeme hukuku dalı olarak ceza muhakemeleri hukuku, (17. Bask1). İstanbul: Kazanc1 Matbaacilık.

Kunter, N., Yenisey, F. ve Nuhoğlu A. (2010). Ceza muhakemesi hukuku, (18. Bask1). İstanbul: Seçkin Yayınları,

Özbek, V. Ö., Kanbur, M. N., Doğan, K., Bacaksız, P. ve Tepe, İ., (2015). Ceza muhakemesi hukuku, (6.Bask1). Ankara: Seçkin Yayınevi.

Özgenç, İ. (2014). Türk ceza hukuku genel hükümler, (10. Bask1). Ankara: Seçkin Yayınevi.

Öztürk, B., Tezcan, D., Erdem, M. R., Gezer Ö. S., Kırıt Saygılar, Y. F., Özaydın, Ö., Akcan Alan E., Erden Tütüncü, E. (2015). Nazari ve uygulamalı ceza muhakemesi hukuku (9. Baskı). Ankara: Seçkin Yayınevi.

Şahin, C. (2014). Küçüklerin şikâyet ve şikâyetten vazgeçme hakk1, Taad, 16; 291-318.

Şahin, C. (2007). Ceza Muhakemesi Hukuku I. Ankara: Seçkin Yayınları.

Toroslu, N. ve Feyzioğlu, M. (2013). Ceza muhakemesi hukuku, (12. Bask1), Ankara: Savaş Yayınevi.

Türk Dil Kurumu (TDK), (2008). Türkçe Sözlük. http://www.tdk.gov.tr. adresinden 07.11.2018 Tarihinde erişim sağlanmıştır.

Uğur, H. (2007). Ceza muhakemesinde kovuşturma mecburiyeti ilkesinden maslahata uygunluk ilkesine, Tbb Dergisi, 73, 258-267

Yaşar, O., Gökcan, H. T. ve Artuç, M. (2014). Yorumlu-uygulamalı Türk ceza kanunu 2.cilt, (2. Bask1). Ankara: Adalet Yayınevi.

Yenisey, F. ve Nuhoğlu, A. (2013). Yazılı başvuru şartının hukuki niteliği, Kazancı Hukuk Araştırmaları Dergisi, 101; 97-108. 
Yenisey, F. ve Nuhoğlu, A. (2014). Ceza muhakemesi hukuku. İstanbul: Bahçeşehir Üniversitesi Yayınları.

Yenisey, F. (2013). Ceza muhakemesi süjelerinin iradelerinin ceza muhakemesinin yürüyüşüne etkisi sorunu, Prof. Dr. Nur Centel'e Armağan, Marmara Üniversitesi Hukuk Fakültesi Hukuk Araştırmaları Dergisi, 19(2);453-469.

Yılmaz, Z. (2010). Ceza hukukumuzda şikâyet. Ankara: Adalet Yayınevi.

\section{Extended Abstract}

\section{Introduction}

The investigation and prosecution of a criminal offense, as a rule, shall be carried out on the behalf of public, regardless of the will of the victim or the offender (Özgenç, 2014). However, for investigations, prosecutions and other offenses, the law obliges authorized persons to file a complaint. Although the grievance occurs with all elements of an offense, it is obligatory requirement imposed the legislator to punish the offender. To put it in other words, the crime was completed independently of the complaint. However, in order to conduct an investigation and prosecution for this crime, the complaint requirement must be fulfilled (Erem, Danışman and Artuk, 2019).

The right to complain is one of the rights guaranteed in the Constitution and is a public law authority. According to the dictionary of the Turkish Language Association, the right means "justice, what the law requires or divides into each other" (TDK, 2018). The right to complain is not a right in private law, but a public law authority. In the sense of private law, the right is the declaration of will for the realization or protection of the interests or assets protected by law. In fact, these rights are not returned after use, cannot be conditional and can be used in accordance with the rules of honesty. In this sense, the complaint in the sense of private law "is not a right but a public law authority recognized to the individual "(Erem, 2018, p. 44). In this case, the right to complain is a "subjective right of public law". Subjective public law rights have three characteristics. These are the co-existence of the individual and the public interests, the existence of a duty by the state against the right of the individual, and the extension of the legal capacity of the individual (Erem, Danışman and Artuk, 2019). The complaint is made orally, in order to be written or recorded in writing to the competent authorities specified in the law, for the purpose of investigating and prosecuting the crime within 6 months from the date of the actual and the perpetrator's learning, or the authorized representatives of the victim or offender who have been harmed by the victim or the crime due to the action attached to the complaint, is a statement of will for the purpose of punishing the offender.

\section{Right to Complaint}

The grievance may also be lodged after the initiation of a public trial: If the offense is found to be connected to the offense after the prosecution phase, the proceedings continue only "if the victim does not give up the complaint" (CMK 158/6).

\section{Classification Of Complaints}

As crimes are inquired and prosecuted as a rule, the complaint is only brought by the law if the offense is regulated by a complaint (Güngör, 2009). In some cases, the complaint occurs according to the act, and in other cases occurs according to the nature of the offender.

\section{The Legal Nature Of The Complaint}

There is some controversy in terms of the complaint institution on both the TCK and the $\mathrm{CMK}$, and the reason why the complaint belongs to the material law or procedural law. Different opinions have been given to explain the legal nature of the complaint. The opinion that is accepted 
mainly in the teaching is that the complaint is a criminal procedure institution (Centel, Zafer and Çakmut, 2014; Koca and Üzülmez, 2018; Yenisey and Nuhoglu, 2014). Although the grievance occurs with all elements of an offense, it is a mandatory requirement by the legislator to punish the offender. In other words, the offense was completed independently of the complaint, but the complaint requirement must be fulfilled for the investigation and prosecution of this crime (Erem, Danışman and Artuk, 2019). The general provisions regulating the grievance institution are set out in the first book of the Turkish Penal Code titled "Sanctions" and in the third part of the' 'Litigation and Punishment Reduction' titled is arranged. Some authors who consider the place of the complaint have suggested that it is a material criminal law institution. The duration of the complaint is set out in Articles 1,2 and 3 of Article 73 of the "Turkish Criminal Law": 1) Investigations and prosecutions cannot be carried out if no one complains about the crime of investigation and prosecution related to the complaint within six months; (2) This period shall begin from the day on which he / she knows or knows who is the actual and the perpetrator, and (3) if one of the few persons who have the right to complain has a period of six months, the rights of others shall not fall. The complaint period for the offenses subject to the complaint is 6 months from victim's learning the "act" and "perpetrator". The complainer has to learn both the perpetrator and the act in order to use the right to complain (Articles 73/1 and 2) Although the duration of the complaint is stated as 6 months in the first paragraph of the article of the law, in the second paragraph of the same article the 6 not to exceed the statute of limitation 'is taken into consideration, the six-month period for which this right may be used must be in the statute of limitations. This period is final and the right to complain cannot be exercised after the deadline.

Investigation and prosecution of a complaint related to the execution of a criminal offense in the period of the complainer and in accordance with the conditions stipulated by the law after using this right, to withdraw his complaint is called withdrawal of the complaint. The right to complain is to inform the competent authorities that if the victim was harmed by the crime, the complainant will not use his / her right to complain before the expiration of the complaint period. Although there is a great resemblance between the complaint and the written application, there are some differences arising from the legal interest that they protect. In the complaint, "the person who has suffered the crime" is complaining. The complainant compares the damage to the offense and the second damage that the offender may suffer as a result of the offense and the second, if not, does not complain. The complaint was considered to be a criminal procedure because the more serious of the second damage was at the detriment of the public. However, the Board, the Authority or the Fund making the written application makes an assessment that prevents the public from further growing by means of investigation, prosecution, or damage, as a result of the duty given to it by the law, even if there is no person directly affected by the crime. Therefore, the body which is authorized to submit a written application admits whether there is any public interest in conducting investigations or prosecution 